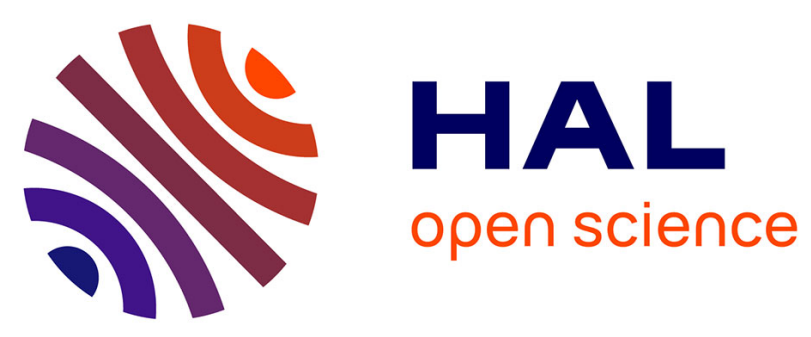

\title{
La Ligue de l'Enseignement
}

Edith Archambault

\section{To cite this version:}

Edith Archambault. La Ligue de l'Enseignement. List R., Anheier H., Toepler S. Editors, International Encyclopedia on Civil Society, 2d Edition, pp.1 - 3, 2021, 10.1007/978-3-319-99675-2_418-1 . halshs03173234

\section{HAL Id: halshs-03173234 https://shs.hal.science/halshs-03173234}

Submitted on 18 Mar 2021

HAL is a multi-disciplinary open access archive for the deposit and dissemination of scientific research documents, whether they are published or not. The documents may come from teaching and research institutions in France or abroad, or from public or private research centers.
L'archive ouverte pluridisciplinaire HAL, est destinée au dépôt et à la diffusion de documents scientifiques de niveau recherche, publiés ou non, émanant des établissements d'enseignement et de recherche français ou étrangers, des laboratoires publics ou privés. 


\section{La Ligue de I'Enseignement}

Edith Archambault

Department of Economics, University of Paris1

Pantheon-Sorbonne, Paris, France

\section{Relevance}

The Ligue de l'Enseignement (Education League) is one of the oldest nonprofit organizations in France; it is also the main champion of the French conception of secularity or laïcité, which is very different from the Anglo-Saxon one. According to this concept, in the public sphere, especially inside public schools and peri-school activity, no reference to faith should be made and no religious signs should be visible. Ligue de l'Enseignement is very close to the public education network and it is the main receiver of public funding.

\section{Address/URL}

3 rue Récamier 75007 Paris France www.laligue.org

\section{Introduction}

Education League is an umbrella of 30,000 French associations of popular education providing services in the fields of culture, sports, recreation, and continuing education. It advocates for secularity, ideological and religious neutrality, and tolerance inside public schools and more generally inside the public sphere.

\section{Brief History}

Founded in 1866 by Jean Macé, a republican journalist, the League fought for a public, lay, free of charge, and compulsory primary education that was finally passed into law in 1882 . After this first success in the long-lasting conflict of influence on education between the state and the Catholic Church, the League reoriented toward peri-school activities and civic and adult education. During World War II, the League was suppressed by the authoritarian government of Vichy and refounded after the war. It remained the champion of the lay/secular camp and the public school during the twentieth century when in the 1950s the government began to subsidize the private schools, mainly Catholic, by paying the teachers. After the cooling down of the school war since the 1980s, the League fought racism, discrimination, and social inequality and promoted solidarity, ecology, and sustainable development. 


\section{Mission and Focus Areas}

The first mission of the League is to complement the education given by the public school during the postschool hours and in the holidays and vacation periods. Its first target group, of course, is youth inside and outside the school but it addresses the adult population as well, especially those who could not complete their school curricula. It advocates also for secularity/laity, fights discrimination against immigrants and other minorities, and promotes civic behavior and European citizenship.

The main focus areas of the League are: affordable sports and recreation activities with an explicit reference to an access to culture for everybody; education toward solidarity, civics, and tolerance; mainstreaming of immigrant youth and their families; education toward the respect of environment; and sustainable development.

\section{Activities}

To fulfill its mission, the League provides a wide range of services for youth and prepares publications intended either for the teachers or for the public at large.

The League gives youth the opportunity to perform arts and sports during their idle hours, inside the school or in community centers, free of charge or at a low price. The League also runs many large facilities used as holiday camps during the vacation periods or welcoming discovery classes during school time. It also organizes linguistic exchanges, the twinning of French and foreign schools or classes. It delivers 10,000 diploma of professional and vocational training for sociocultural animators (BAFA). Since 1999, the League has developed a volunteer association called "read and make read" to prevent the desaffection of children of the digital era for reading books. Lastly, the League supports development projects, mainly in Africa.

Through its website, an annual forum on education, and many debates and publications, the League gives information and references on education, citizenship, secularism, social inclusion, and many other current issues.

\section{Structure and Governance}

The Ligue de l'Enseignement is an umbrella of 103 departmental federations grouping 30,000 local associations. It includes also specialized subsidiaries for sports or social tourism. It enjoys strong ties with the main teachers' labor union and the main parent-teacher association. The indirect membership is $1,800,000$ families. The League employs 5,000 employees but local associations rely mainly on 500,000 volunteers, either parents or teachers, and 18,000 civic service volunteers. Its board is composed of 36 persons, and its executive bureau includes 17 persons.

The League is affiliated with European platforms on education and with networks or INGOs, such as Solidar and the European Civic Forum.

\section{Funding}

The two main resources of the League are membership dues and users' fees on the one hand, and public funding, either subsidies or contracts, on the other hand. Public funding includes the payment of teachers seconded by government to the League. Private donations play a more symbolic role in the League's resources.

\section{Major Accomplishments}

The impact of the Ligue de l'Enseignement on the French civil society is deep-rooted as the League played a major role in defining the French concept of secularism, which was difficult to explain to foreigners: the fight against wearing an Islamic scarf inside the school is one example. More generally, the League was, and still is, a major actor in popular education, democratization of culture and human rights defense, and one of the leaders of the nonprofit world in France.

Two Nobel Peace Prizes were awarded to the second and the third presidents of the League, in 1920 and 1927, respectively: Léon Bourgeois, who was also the first president of the League of Nations, and Ferdinand Buisson, who founded the Human Rights League. 


\section{Cross-References}

- Civil Society and Civic Education

$\checkmark$ Human Rights

$\checkmark$ INGOs

- Umbrella Organizations

\section{References}

Ducomte, J. M., Martin, J. P., \& Roman, J. (2013). Anthologie de l'éducation populaire. Paris: Privat, coll. "Le Comptoir des idées".

Tournemire, P. (2000). La Ligue de l'Enseignement. Paris: Milan. 